\title{
Human rights-based approach to tobacco control
}

\author{
Carolyn Dresler, ${ }^{1}$ Harry Lando, ${ }^{2}$ Nick Schneider, ${ }^{3}$ Hitakshi Sehgal ${ }^{4}$
}

${ }^{1}$ Arkansas Department of Health, Little Rock, Arkansas, USA

${ }^{2}$ Division of Epidemiology and Community Health, School of Public Health, University of Minnesota, Minneapolis, USA

${ }^{3}$ German Cancer Research Center, Unit Cancer Prevention and WHO Collaborating Centre for Tobacco Control, Heidelberg, Germany

${ }^{4}$ School of Public Health, University of Minnesota, Minneapolis, USA

\section{Correspondence to} Dr Carolyn Dresler, Arkansas Department of Health, 4815 West Markham St. Little Rock, Arkansas 72207, USA; carolyn dresler@ksg03. harvard.edu

Received 5 April 2011 Accepted 29 August 2011

\begin{abstract}
The Framework Convention for Tobacco Control (FCTC) is currently the most potent tool for implementation of tobacco control laws across the globe. The FCTC is derivative from previously constructed international human rights conventions. These previous conventions have enforcement mechanisms, unlike the FCTC. However, the FCTC relies on state parties to report periodically on its implementation rather than on a continuous monitoring system. The Human Rights and Tobacco Control Network proposes that abiding by the principles of human rights delineated by international treaties, citizens across the globe can demand effective action for tobacco control. This paper explains the link between fundamental human rights and the right to tobacco control. Mechanisms are described to link the FCTC and its principles with human rights-based monitoring reports, which are provided to oversight committees for the other human rights conventions. The initial work of the Human Rights and Tobacco Control Network is summarised and considers the future directions for the human rights-based approach to tobacco control.
\end{abstract}

\section{HUMAN RIGHTS-BASED APPROACH TO TOBACCO CONTROL}

Human rights rhetoric became universally defined with the Universal Declaration of Human Rights in 1948, specifically related to health with: 'the right to a standard of living adequate for health and well-being of himself and his family, including food, clothing, housing and medical care and necessary social service'. ${ }^{1}$ Since then, nine core international human rights treaties have been adopted and brought into force (table 1). Of particular relevance to the rights relative to health and well-being, under which tobacco control would be pertinent are: the International Covenant on Civil and Political Rights (ICCPR, 1966), the International Covenant on Economic, Social and Cultural Rights (ICESCR, 1966), the Convention on the Elimination on Discrimination Against Women (CEDAW, 1979) and the Convention on the Rights of the Child (CRC, 1989). To ensure that the agreed rights are also enjoyed in practice, each of these treaties has clear and independent mechanisms to monitor the implementation of the respective treaty provisions.

Unlike the WHO Framework Convention on Tobacco Control (FCTC), ${ }^{2}$ the core human rights treaties rely on periodic reporting by the state parties and additionally have international committees of independent experts (treaty bodies) to regularly monitor national implementation and report back to the UN system. These treaty bodies consist of 10 to 23 internationally recognised independent experts who are nominated and elected by state parties. The committees receive reports from state parties as well as additional information on the human rights situation in the respective country, examine them in a dialogue with government representatives and publish their concerns and recommendations as 'concluding observations/comments'. Some treaty bodies introduced further monitoring mechanisms including an enquiry procedure, the examination of interstate complaints and the examination of individual complaints (table 1). The treaties complement each other, are interdependent and mutually reinforcing. That said, many countries have derogated from important portions of treaties, have ignored implementation or adherence because of lack of will or ability to do so. Often the ability to adhere or progress on treaty implementation is hampered by financial constraints. If there are not financial resources to allow full implementation of a treaty requirement, then progressive realisation of the right is to be expected as finances allow.

A key principle underpinning human rights is the recognition of states' obligations to respect, protect and fulfil these international rights. Most states in the world are party to most of the human rights conventions, the USA unfortunately being a notable exception. An excellent example is Uruguay, which is party to the nine core human rights treaties, but significantly the ICESCR, CEDAW, CRC and the FCTC, and works diligently to respect, protect and fulfil fundamental human rights-pertinently, as they apply to tobacco control. ${ }^{3}$ Uruguay has established comprehensive smoke-free laws, dedicated a portion of its tobacco tax to health related purposes, has required pictorial warnings on cigarettes packs, has banned electronic cigarettes and has established evidence-based tobacco cessation guidelines that include support for nicotine replacement and bupropion.

\section{FROM THE RIGHT TO HEALTH TO THE RIGHT TO TOBACCO CONTROL?}

By tightly adhering to the principles that have been delineated for interpreting human rights, one can construct legal claims to rights related to tobacco control. ${ }^{4}$ These would include human rights more broadly than just the right to health. All human rights are inter-related, interdependent and indivisible. States have a duty (see http://plato. stanford.edu/entries/rights-human/ for discussion of rights and duties) to provide all human rights to the best of their economic and political ability. In many poorly resourced countries this can be difficult as the tobacco industry, with its unlimited resources, can overwhelm states' best intentions to comply with health-based rights by using those resources 
Table 1 Monitoring instruments and complaints procedures contained in the UN Human Rights Treaties vis à vis the WHO Framework Convention on Tobacco Control

\begin{tabular}{|c|c|c|c|c|c|c|c|}
\hline \multirow[b]{2}{*}{$\begin{array}{l}\text { Multilateral treaty (acronym, } \\
\text { year of adoption); optional } \\
\text { protocols }\end{array}$} & \multirow[b]{2}{*}{$\begin{array}{l}\text { State reporting } \\
\text { obligations (in } \\
\text { years after acceding) }\end{array}$} & \multicolumn{2}{|c|}{ Expert committee } & \multicolumn{4}{|c|}{ Additional complaints procedures } \\
\hline & & $\begin{array}{l}\text { Monitoring by } \\
\text { expert } \\
\text { committee }\end{array}$ & $\begin{array}{l}\text { Number and lengths } \\
\text { of sessions }\end{array}$ & $\begin{array}{l}\text { Individual } \\
\text { complaints/ } \\
\text { communications }\end{array}$ & $\begin{array}{l}\text { Interstate } \\
\text { complaints }\end{array}$ & $\begin{array}{l}\text { Enquiries } \\
\text { (by the } \\
\text { committee) }\end{array}$ & Other \\
\hline \multicolumn{8}{|l|}{ UN human rights treaties } \\
\hline $\begin{array}{l}\text { International Convention on } \\
\text { the Elimination of all forms } \\
\text { of Racial Discrimination } \\
\text { (ICERD, 1965) }\end{array}$ & $\begin{array}{l}\text { One or more every } \\
2 \text { years }\end{array}$ & Yes & Two per year, 3 weeks each & Yes & Yes & - & $\begin{array}{l}\text { Early } \\
\text { warnings }\end{array}$ \\
\hline $\begin{array}{l}\text { International Covenant on } \\
\text { Civil and Political Rights } \\
\text { (ICCPR, 1966) and two } \\
\text { optional protocols }\end{array}$ & $\begin{array}{l}\text { One year after } \\
\text { acceding then upon } \\
\text { request, usually every } \\
4 \text { years }\end{array}$ & Yes & Three per year, 3 weeks each & Yes & Yes & - & - \\
\hline $\begin{array}{l}\text { International Covenant on } \\
\text { Economic, Social and } \\
\text { Cultural Rights (ICESCR, } \\
1966 \text { ) and one optional } \\
\text { protocol }\end{array}$ & $\begin{array}{l}\text { Two or more every } \\
5 \text { years }\end{array}$ & Yes & $\begin{array}{l}\text { Two per year, } 3 \text { weeks } \\
\text { plenary and } 1 \text { week working } \\
\text { group prior to session }\end{array}$ & Yes & - & - & - \\
\hline $\begin{array}{l}\text { Convention on the } \\
\text { Elimination of all forms } \\
\text { of Discrimination Against } \\
\text { Women (CEDAW, 1979) }\end{array}$ & $\begin{array}{l}\text { One or more upon } \\
\text { request (at least } \\
\text { every } 4 \text { years) }\end{array}$ & Yes & One per year, maximum 2 weeks & Yes & - & Yes & - \\
\hline $\begin{array}{l}\text { Convention Against Torture } \\
\text { and Other Cruel, Inhuman } \\
\text { or Degrading Treatment or } \\
\text { Punishment (CAT, 1984) } \\
\text { and one optional protocol }\end{array}$ & $\begin{array}{l}\text { One or more every } \\
4 \text { years }\end{array}$ & Yes & Two per year, 3 weeks each & Yes & Yes & Yes & Inspections \\
\hline $\begin{array}{l}\text { Convention on the Rights } \\
\text { of the Child (CRC, 1989) } \\
\text { and two optional protocols }\end{array}$ & $\begin{array}{l}\text { Two years after } \\
\text { acceding, then every } \\
5 \text { years }\end{array}$ & Yes & $\begin{array}{l}\text { Three per year, } 3 \text { weeks } \\
\text { plenary and } 1 \text { week } \\
\text { working group prior to } \\
\text { session }\end{array}$ & - & Yes & - & - \\
\hline $\begin{array}{l}\text { International Convention } \\
\text { on the Protection of the } \\
\text { Rights of all Migrant } \\
\text { Workers and Members of } \\
\text { their Families (ICPMW, } \\
\text { 1990) }\end{array}$ & $\begin{array}{l}\text { One or more every } \\
5 \text { years }\end{array}$ & Yes & Two per year, 1 week each & Yes & - & - & - \\
\hline $\begin{array}{l}\text { International Convention for } \\
\text { the Protection of all } \\
\text { Persons from Enforced } \\
\text { Disappearance } \\
\text { (CPED, 2006) }\end{array}$ & $\begin{array}{l}\text { Two or more upon } \\
\text { request }\end{array}$ & Yes & Two per year & Yes & - & - & - \\
\hline $\begin{array}{l}\text { Convention on the Rights of } \\
\text { Persons with Disabilities } \\
\text { (CRPD, 2006), } \\
\text { one optional protocol }\end{array}$ & $\begin{array}{l}\text { Two or more every } \\
4 \text { years }\end{array}$ & Yes & Two per year, 1 week each & Yes & - & - & - \\
\hline \multicolumn{8}{|c|}{ Multilateral public health treaties (WHO) } \\
\hline $\begin{array}{l}\text { WHO framework convention } \\
\text { on tobacco Control (FCTC, } \\
\text { 2003) }\end{array}$ & $\begin{array}{l}\text { Two years after } \\
\text { acceding, then every } \\
5 \text { years until } 2012 \text {, } \\
\text { then every } 2 \text { years }\end{array}$ & - & - & - & - & - & - \\
\hline
\end{tabular}

strategically in ways that undermine tobacco control progress. States and their citizens must be empowered with knowledge, resources and ability to claim their rights and resist the tobacco industry's 'corporate social responsibility', 'corporate social investment' or outright bribery that can inhibit realisations of such rights. An example of tobacco industry corporate social responsibility is the establishment by the tobacco industry of Eliminating Child Labour in Tobacco Growing, while hundreds of thousands of children are still working in tobacco production (including bidi rolling). ${ }^{5}$ Educated and empowered citizens give the human rights-based approach to tobacco control its utility. The right to health, or the right to the highest attainable standard of health, is claimed within Article 12 of the ICESCR. This right is then further elucidated and defined within a structure that is called a General Comment (see box 1). The key axioms that underpin a human rights-based approach to tobacco control are derived from Article 12 of the ICESCR, General Comment 14:
1. The States Parties to the present Covenant recognise the right of everyone to the enjoyment of the highest attainable standard of physical and mental health.

2. ....(b): The improvement of all aspects of environmental and industrial hygiene; (c) The prevention, treatment and control of epidemic, endemic, occupational and other diseases;...

Protection from secondhand smoke, tobacco production regulation, marketing restrictions and efforts to decrease tobacco consumption are clearly covered by General Comment 14 (see box 1).

Besides the right to health, however, there are several other human rights equally important to respect, protect and fulfil. For example, the right to a healthy environment (consider secondhand smoke or protection from nicotine from green tobacco sickness, or exposure to pesticides during tobacco agriculture); right to information (consider knowledge relative to risks of nicotine addiction, risks from tobacco use such as lung cancer or vascular disease, risk from exposure to secondhand 
Box 1 Technical explanations of General Comment (GC) and pertinent language within the International Covenant on Economic, Social and Cultural Rights (ICESCR) relative to tobacco control

A 'General Comment' (GC) is an elucidation and expansion of the intent of the phrasing within a Convention. In this instance, GC 14 further defines the intent of the right to health proscribed within Article 12 of the ICESCR.

Pertinent to tobacco control, General Comment 14 maintains: Violations of the obligation to protect follow from the failure of a state to take all necessary measures to safeguard persons within their jurisdiction from infringements of the right to health by third parties. This category includes such omissions as the failure to regulate the activities of individuals, groups or corporations so as to prevent them from violating the right to health of others; the failure to protect consumers and workers from practices detrimental to health, for example by employers and manufacturers of medicines or food; the failure to discourage production, marketing and consumption of tobacco, narcotics and other harmful substances. Sources: http://www.ohchr.org; http:// www.who.int/fctc.

smoke, risk from exposure to tobacco agriculture: nicotine, fertilizers, pesticides etc.); right to education (consider children kept from school for tobacco agriculture); right to a sustainable income (consider indentured servitude or 'company store'); right to a standard of living adequate for the child's physical, mental, spiritual, moral and social development (consider use of limited family income to purchase tobacco rather than food). A human rights approach can readily work within the Articles of the FCTC, along with other international conventions and treaties to help enforce their intent.

\section{FROM THEORY TO ACTION: THE USE OF SHADOW REPORTS}

Several methodologies are being explored to use the human rights-based approach to tobacco control. Claims can be brought to appropriate courts that oversee regional human rights conventions. For example, the European Convention on Human Rights, the African Commission on Human and People's Rights and the Inter-American Commission have respective Courts to enforce their conventions. These courts are available to individuals, such as the successful appeal of a non-smoker in a Russian prison to the European Court, which found a violation of the European Convention and awarded damages. ${ }^{4}$

'Shadow reports' are another established method for providing information to the different treaty-reviewing committees to assist in their assessments of official state reports. Parties to the different conventions are required to submit state reports on their fulfilment of the requirements of the treaty. Shadow reports are submitted by interested non-state parties; for example, non-governmental organisations within the country, that help provide evidence on the progress of the state in implementation of the treaty. These shadow reports can more clearly and explicitly address progress or the lack of progress that the state is achieving in tobacco control. Reviewing committees can then recommend improvements/remedies for the country to pursue; for example, the treaty-body Committee with oversight for the ICESCR or CESCR recommended 'that the state party take measures to ban the promotion of tobacco products and enact legislation to ensure that all enclosed public environments are completely free of tobacco'. ${ }^{3}$ In addition, the CESCR had recommendations for Brazil concerning child labour, slavery and deforestation (although not specifically in reference to tobacco agriculture). ${ }^{6}$

\section{ACTIVITIES SO FAR: THE HUMAN RIGHTS AND TOBACCO CONTROL NETWORK (HRTCN)}

To develop action plans for using a human rights-based approach in tobacco control, a small cadre of tobacco control advocates from multidisciplinary backgrounds met in Lausanne, Switzerland in 2008 and established the HRTCN (http://www. hrtcn.net). Two other meetings followed, one in conjunction with the World Conference on Tobacco or Health in Mumbai in 2009 and a working group meeting with the WHO human rights and tobacco control units in Geneva in 2010. HRTCN networks with partners around the world to connect and educate about the power of the human rights approach to advance tobacco control. These partners come from diverse backgrounds, including medicine and nursing, social scientists, faith communities, legal experts, tobacco control advocates and others; this provides for diverse perspectives. For example, many tobacco control advocates are firmly opposed to any negotiations with the tobacco industry, whereas others have vigorously engaged in such negotiations in order to advance goals such as labour rights. A pilot project is to develop an approach to inform the Committees of pertinent Conventions, such as the CESCR, by using 'short' reports. Global HRTCN partners are piloting a review of each of the country reports to the CESCR and are preparing one-page summary documents. These elucidate key tobacco control issues and progress or lack of progress by individual countries. For example, it might be noted that a country has ratified the FCTC, but has no comprehensive secondhand smoke exposure law, or continues to tolerate use of child labour in tobacco agriculture. Such information should be useful for the committees, specifically for the ICESCR, CEDAW and the CRC, as they formulate their country specific recommendations; figure 1 .

\section{THE FUTURE: INTEGRATION OF A TOBACCO CONTROL BASED APPROACH IN HUMAN RIGHTS MONITORING?}

The WHO FCTC reporting instrument includes an extensive set of indicators for monitoring its implementation on national levels. WHO and the FCTC Secretariat could provide relevant input to the respective treaty bodies, for example by sharing the FCTC implementation reports or by presenting findings at committee sessions. The UN Ad Hoc Interagency Task Force on Tobacco Control meets every 2 years and, at the last meeting, the first author presented on the human rights-based approach to tobacco control. The WHO's Health and Human Rights Team is active and supportive of a human rights-based approach to tobacco control, and hosted a meeting in 2010 where relevant treaty representatives (CEDAW, CRC, ICESCR) were actively engaged. The UN Task Force on Tobacco Control offers an ideal platform to provide collaboration and exchange of information regarding common areas of interest, such as the right to a healthy environment (secondhand smoke or green tobacco sickness) or the right to education (knowledge of the harm of tobacco use) and other rights covered in different legal instruments. Incorporation of tobacco-related indicators in the monitoring mechanisms of human rights treaties appears to be a feasible option to support implementation of the FCTC in the absence of an independent monitoring mechanism. Additional input could be provided by academia and civil society involved in tobacco control, as well as other entities involved in human rights advocacy and research. In order to facilitate this process, national and international training and capacity building should 

the human rights treaties and opportunities for input related to tobacco control (adapted from the Office of the United Nations High Commissioner for Human Rights, The United Nations Human Rights Treaty System, Factsheet 30) ${ }^{7}$. FCTC, WHO Framework Convention on Tobacco Control; NGO, non-governmental organisation; TFI, WHO Tobacco-Free Initiative.
Figure 1 The reporting cycle under

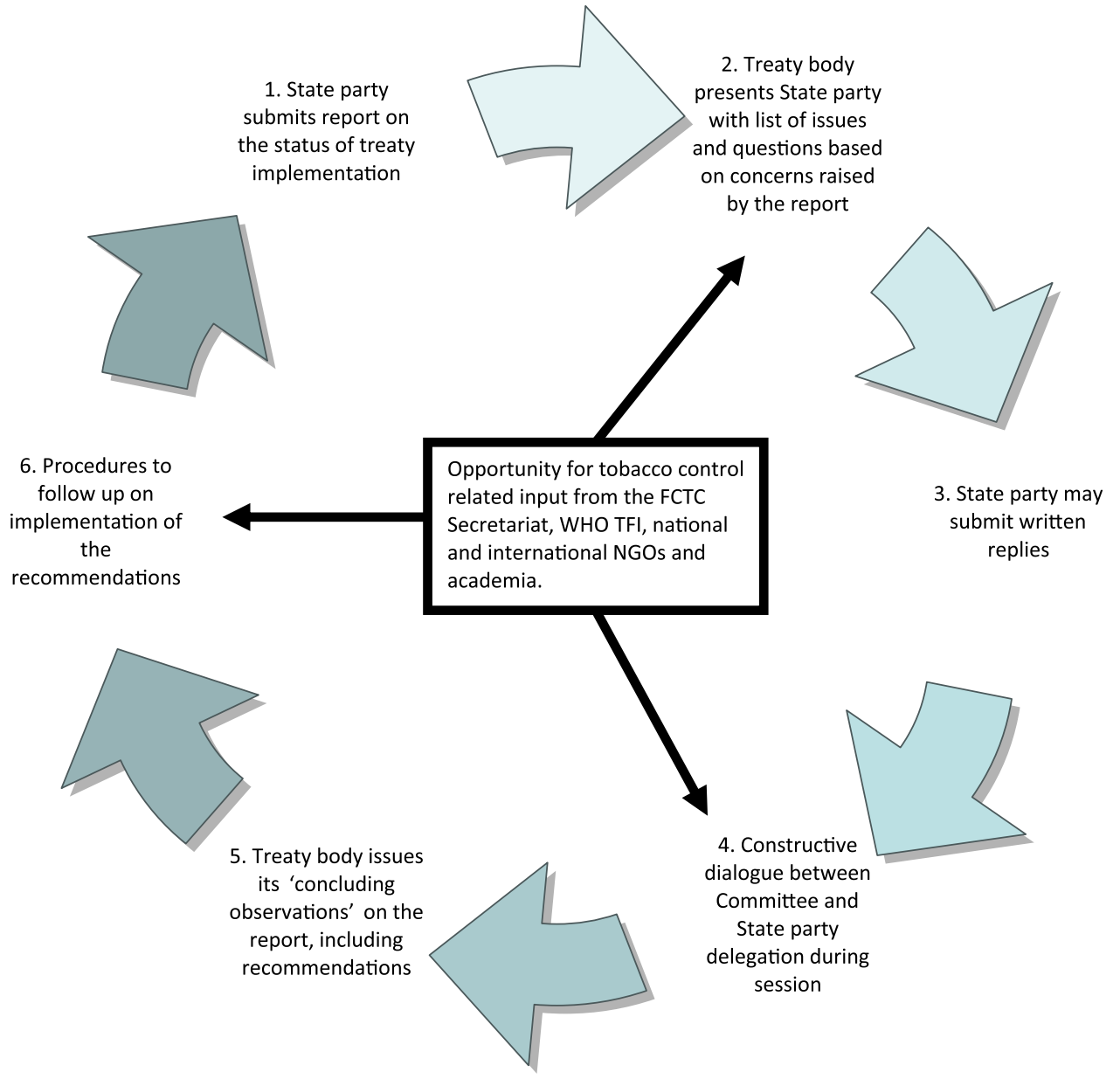

be supported, for example in writing shadow reports and participation in hearings during committee sessions.

The complaint procedures contained in some of the treaties could be used to communicate tobacco control related human rights violations to the respective committees. Under particular circumstances, CEDAW and CRC may consider complaints from individuals or from third parties representing individuals whose rights have been violated. As discussed above, individuals can bring a claim to one of the regional courts, or, if their country is party to the ICESCR, an individual could petition his/her own country for a legal remedy. Another opportunity is to engage the Special Rapporteur on the right of everyone to the highest attainable standard of physical and mental health in helping to expose human rights violations promulgated by the tobacco

\section{What this paper adds}

There has been much work over the past 20 years developing the rhetoric of a human rights-based approach to health issues. The Framework Convention on Tobacco Control was patterned after previous human rights conventions. A human rights-based approach to tobacco control could provide new approaches to the effort.

- The concept from a right to health to a right to tobacco control is developed. Methods are explained to use currently available mechanisms to advance a human rights-based approach to tobacco control, including establishment of the Human Rights and Tobacco Control Network. industry, including agricultural and manufacturing abuses. In addition, calling for a General Day of Discussion on Tobacco Control at the United Nations could lead to a General Comment for Article 12 of the ICESCR on the right to tobacco control and could further spur compliance and implementation of the FCTC. In the interim, tobacco control with implementation of the Framework Convention should be included in the upcoming high level meeting on 20-21 September 2011 on non-communicable diseases, particularly as they relate to developing countries.

Competing interests None.

Contributors All of the authors contributed to the concept and construction of the paper.

Provenance and peer review Commissioned; externally peer reviewed.

\section{REFERENCES}

1. The United Nations Declaration of Human Rights; United Nations website. http://www.un.org/en/documents/udhr/index.shtml (accessed 13 Mar 2011).

2. The Framework Convention on Tobacco Control; World Health Organization website. http://www.who.int/fctc/en/ (accessed 13 Mar 2011).

3. Cabrera OA, Madrazo A. Human rights as a tool for tobacco control in Latin America. Salud Publica de México 2010;52(Suppl 2):S228-97.

4. Dresler $\mathbf{C M}$, Marks S. The emerging human right to tobacco control. Hum Right 0 2006;28:599-651.

5. http://www.independent.co.uk/life-style/health-and-families/health-news/theunstoppable-march-of-the-tobacco-giants-2290583.html (accessed 10 Jun 2011).

6. Office of United Nations High Commissioner on Human Rights; Committee on Economic, Social and Cultural Rights review of Brazil Country Report. http://www2.ohchr.org/english/bodies/cescr/cescrs42.htm (accessed 27 Feb 2011).

7. Office of the United Nations High Commissioner for Human Rights. The United Nations Human Rights Treaty System: An Introduction to the Core Human Rights Treaties and the Treaty Bodies. Fact Sheet No.30. Geneva, 2005. http://www.ohchr.org/Documents/Publications/FactSheet30en.pdf (accessed 10 Mar 2011). 